\title{
论 文
}

\section{大鼠 8 种肝脏细胞中缺血反应相关基因与肝再生的 作用分析}

\author{
方方 ${ }^{(12)}$ ，徐存拴 ${ }^{2 *}$ \\ (1) 新乡医学院人体解剖学教研室, 新乡 453003; \\ (2) 河南师范大学生命科学学院, 省部共建细胞分化调控国家重点实验室, 新乡 453007 \\ * 联系人, E-mail: xuncunshuan@163.com \\ 收稿日期: 2010-04-26; 接受日期: 2010-07-20 \\ 国家重点基础研究发展计划(批准号: 2006CB708506)资助项目
}

\begin{abstract}
摘要 为了解 8 种肝脏细胞的缺血反应相关基因与大鼠肝再生的相关性, 用 percoll 密度梯度离心和免疫磁珠方法分离大鼠部分肝切除后不同时间 $(0,2,6,12,24,30,36$, 72,120 和 $168 \mathrm{~h}$ )再生肝中的 8 种细胞, 用 Rat Genome 2302.0 芯片等方法检测上述 8 种细胞的缺血反应相关基因在大鼠肝再生中表达变化, 用生物学和系统生物学等方 法分析上述基因与大鼠肝再生的相关性. 结果显示, 缺血反应主要在肝再生启动阶段 及进展阶段前期发挥作用，且上调占优势，可刺激il6, thf 等肝再生关键基因表达; 肝 星形细胞、树突状细胞中的缺血反应相关基因具有表达的相似性. 缺血反应能推动肝 再生的顺利进行, 但胆管上皮细胞的基因表达情况特殊, 值得进一步研究.
\end{abstract}

\section{关键词}

肝再生

部分肝切除

Rat Genome 2302.0 芯片

缺血反应
肝脏是机体的重要器官 ${ }^{[1]}$, 有很强的再生能力. 部分肝切除(partial hepatectomy, PH)后, 残肝细胞通 过增殖和组织结构功能重建以补偿丢失的肝组织, 这个过程称为肝再生(liver regeneration, LR) ${ }^{[2,3]}$. 根据 肝再生的时间进程和生理生化活动变化将肝再生分 为启动 $(\mathrm{PH}$ 后 2 6 h)、进展 $(\mathrm{PH}$ 后 6 72 h) 和终止 $(\mathrm{PH}$ 后 72 168 h)3 个阶段 ${ }^{[4]}$, 涉及细胞激活、去分化、增 殖及调控、再分化、组织结构功能重建等生理生化活 动. PH 后由于血管重建 ${ }^{[5]}$ 及血流方向改变 ${ }^{[6]}$ 等原因会 造成生理性局部缺血反应, 该反应对肝再生有何影 响尚无定论.

肝脏由多种细胞构成, 细胞之间还存在相互作 用. 因此, 本文用 Rat Genome 2302.0 芯片检测大鼠 2/3 肝切除后再生肝不同时间点的肝细胞(hepatocyte,
$\mathrm{HC}$ )、胆管上皮细胞 (biliary epithelial cell, BEC)、 Kupffer 细胞 (Kupffer cell, $\mathrm{KC}$ )、窦内皮细胞 (sinusoidal endothelial cell, SEC)、肝星形细胞(hepatic stellate cell, HSC)、树突状细胞(dendritic cell, DC)、 陷窝细胞(lacunar cell, LC)和卵圆细胞(oval cell, OC) 8 种肝脏分离细胞的表达情况, 从细胞水平上进一步 研究缺血反应与肝再生.

\section{1 材料与方法}

\section{1 大鼠再生肝的细胞分散及 8 种肝脏细胞的分离} 实验用 SD纯系大鼠由河南师范大学实验动物中 心提供, 体重 $(230 \pm 20) \mathrm{g}$. 将 108 只大鼠随机分为 19 组, 每组 6 只. 其中, 9 组为部分肝切除, 9 组为手术

引用格式: 方方, 徐存拴. 大鼠 8 种肝脏细胞中缺血反应相关基因与肝再生的作用分析. 中国科学: 生命科学, 2010, 40: 704一 717, doi: 10.1360/052010-252 
对照, 1 组用于正常对照 ${ }^{[7]}$. 部分肝切除按 Higgins 和 Anderson ${ }^{[8]}$ 的方法进行, 并于 PH 后 $0,2,6,12,24,30$, $36,72,120$ 和 $168 \mathrm{~h}$ 取相应大鼠. 实验中严格遵循中 国动物保护法.

取上述大鼠, 乙醚吸入麻醉, 酒精腹部消毒, 打 开腹腔, 暴露肝脏, 结扎肝脏的上下腔静脉, 在门静 脉插管, 用无铻灌流液灌流洗去肝内血液, 接着灌流 0.05\%胶原酶分散肝脏细胞. 收集分散良好的肝脏细 胞, PBS 洗涤 3 次, 把细胞浓度调至 $1 \times 10^{8}$ 个 $/ \mathrm{mL}$, 取

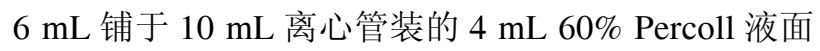
上, $4^{\circ} \mathrm{C}, 200 \times g$ 离心 $5 \mathrm{~min}$, 获得沉淀和上清, 收集沉 淀即为分离纯化的肝细胞 ${ }^{[9]}$. 在上清中加入等体积 $\mathrm{PBS}$, 混匀, $4^{\circ} \mathrm{C}, 400 \times g$ 离心 2 次, 各 $2 \mathrm{~min}$, 收集沉淀 备用. 在分离胆管上皮细胞时, 取消化良好的肝脏, 仔细剥离肝脏表面的被膜后, 将肝脏剪成碎块, 置于 含 $0.05 \% \mathrm{IV}$ 型胶原酶中, $37^{\circ} \mathrm{C}$ 震荡消化 $15 \mathrm{~min} ; 200$ 目尼龙网过滤, 取网上组织碎片, 继续于 $37^{\circ} \mathrm{C}$ 振荡 消化, 使呈白色的肝内胆管游离出来; 将白色肝内胆 管置于含 $0.25 \%$ 胰蛋白酶及 $0.05 \%$ 胶原酶的消化液中, $37^{\circ} \mathrm{C}$ 振荡 $50 \mathrm{~min}, 300 \times \mathrm{g}$ 离心, 收集沉淀备用. 将上 述收集沉淀的细胞浓度调至 $1 \times 10^{8}$ 个 $/ \mathrm{mL}$, 按 $1 \mathrm{~mL}$ 加 $10 \mu \mathrm{L}$ thy-1, GFAP, CK19, CD68, CD161a, CD11c, $\mathrm{CD} 31$ 抗 $\mathrm{PE}$ 抗体, $4^{\circ} \mathrm{C}$ 睬育 $15 \mathrm{~min}$, 按 $1 \mathrm{~mL}$ 加 $10 \mu \mathrm{L}$ 抗 $\mathrm{PE}$ 分选磁珠, $4^{\circ} \mathrm{C}$ 捊育 $15 \mathrm{~min}$, 将细胞悬液加入分 选柱中, 待细胞悬液自然流出后, $4^{\circ} \mathrm{C}$ PBS 洗分选柱 2 次, 移去分选磁场, 加 $4^{\circ} \mathrm{C}$ PBS 冲洗分选柱, 收集 的洗液相应含 $\mathrm{OC}^{[10]}, \mathrm{HSC}^{[11]}, \mathrm{SEC}^{[12]}, \mathrm{KC}^{[13]}, \mathrm{LC}^{[14]}$, $\mathrm{DC}^{[15]}$ 及 $\mathrm{BEC}^{[16]}$.

\section{2 再生肝 8 种细胞的鉴定}

取上述分离出的 8 种肝脏细胞悬液各 $20 \mu \mathrm{L}$, 加 $5 \mathrm{~mL} 10 \%$ 中性甲醛固定细胞 $30 \mathrm{~min}$, 滴片, 自然干 燥. 滴加 $3 \% \mathrm{H}_{2} \mathrm{O}_{2}$, 室温静置 $10 \mathrm{~min}, \mathrm{PBS}$ 洗片 3 次, 各 5 min. 再滴加 $2 \%$ Triton X-100, 室温静置 15 min, PBS 洗片 3 次, 各 $5 \mathrm{~min}$. 将玻片放入柠檬酸缓冲液中, 于微波炉内蒸煮至沸腾, 自然冷却缓冲液至室温, 重 复 1 次, PBS 洗片 3 次, 各 $5 \mathrm{~min}$. 滴加正常羊血清, 室 温封闭 $30 \mathrm{~min}$, 然后甩去血清, 分别滴加 $1: 200$ (体 积比)稀释的鉴定 HC, BEC, OC, HSC, SEC, KC, LC, DC 的一抗 ALB, CK18, OC2, DES, CD14, LYZ, CD8, $\mathrm{CD} 86,4^{\circ} \mathrm{C}$ 睬育过夜 (同时, 用 $\mathrm{PBS}$ 代替一抗作空白对 照). PBS 洗片 3 次, 各 $5 \mathrm{~min}$ 后, 相应地滴加 1 :
2000 (体积比)稀释的兔抗羊和羊抗兔的生物素化二 抗, $37^{\circ} \mathrm{C}$ 捊育 $60 \mathrm{~min}, \mathrm{PBS}$ 洗涤 3 次, 各 $5 \mathrm{~min}$. 滴加 $\mathrm{SABC}, 37^{\circ} \mathrm{C}$ 捊育 $30 \mathrm{~min}, \mathrm{PBS}$ 洗涤 3 次, 各 $5 \mathrm{~min}$. 滴 加 $\mathrm{DAB}$ 显色剂, 镜检出现棕黄色阳性细胞时, 即用 流水冲洗玻片 $30 \mathrm{~min}$ 终止显色 ${ }^{[17]}$. 将玻片浸于苏木 精染液中复染 $5 \mathrm{~min}$, 流水冲洗 $5 \mathrm{~min}$, 再置入酒精盐 酸中 5 30 s(根据染色效果设定酒精盐酸脱色时间), 流水冲洗 $5 \mathrm{~min}^{[17]}$. 最后, 将复染后的玻片在稀氨水 中返蓝 $30 \mathrm{~s}$, 封片. Nikon ECLIPSE 80i 镜下观察、拍 照, 每张玻片至少计数 5000 个细胞, 计算阳性细胞 百分率 ${ }^{[18]}$.

\subsection{Rat Genome 2302.0 芯片检测及分析}

总 RNA 提取按 Invitrogen 公司的 Trizol 试剂盒 操作指南进行 ${ }^{[19]}$, 总 RNA 纯化按 QIAGEN 公司的 RNeasy Mini 试剂盒操作指南进行 ${ }^{[20]}$. 在 $A_{260 / 280}$ 下测 定总 RNA 浓度和纯度 ${ }^{[21]}$. 用琼脂糖凝胶电泳 $(180 \mathrm{~V}$, $0.5 \mathrm{~h}$ )检测总 RNA 质量, 实验用样品的 $28 \mathrm{~S}$ 和 $18 \mathrm{~S}$ 亮度比例约为 $2: 1$ 的 RNA. 以 T7-(dT) ${ }_{24}$ Primer 作引 物, 取 $5 \mu \mathrm{g}$ 总 RNA 作模板, 通过 SuperScript II RT 反转录系统合成 cDNA 第 1 条链, 按 Affymetrix cDNA 单链合成试剂盒操作指南合成 cDNA 第 2 条链. 按 $\mathrm{cDNA}$ 纯化指南纯化 $\mathrm{cDNA}^{[22]}$. 用 $12 \mu \mathrm{L}$ 上述纯化 的 cDNA 作模板, 按 GeneChip IVT 标记试剂盒操作 指南合成生物素标记的 cRNA, 最后按 cRNA 纯化 指南纯化 $\mathrm{cRNA}^{[23]}$. 两者的浓度、纯度和质量检测方 法同上. 在 $15 \mu \mathrm{L}$ 浓度为 $1 \mu \mathrm{g} / \mu \mathrm{L}$ 的 cRNA 溶液中加 入 $6 \mu \mathrm{L} 5 \times$ 片段化缓冲液和 $9 \mu \mathrm{L}$ 无 RNA 酶水混匀, $94^{\circ} \mathrm{C}$ 温浴 $35 \mathrm{~min}$, 得到长度为 $35 \sim 200 \mathrm{bp}$ 的 cRNA 片 段. 按 Affymetrix 公司提供的配方配制杂交液, 将经 过预杂交处理的 Rat Genome 2302.0 芯片放入杂交液 中, 于 $45^{\circ} \mathrm{C}, 60 \mathrm{r} / \mathrm{min}$ 条件下杂交 $16 \mathrm{~h}$ 后吸去杂交液. 芯片在 GeneChip 全自动洗涤工作站 450(Affymetrix 公司, USA)中洗涤和染色, 最后用高分辨芯片扫描仪 3000(Affymetrix 公司, USA)扫描芯片, 获得扫描图 像 ${ }^{[23]}$. 用 Affymetrix GCOS 1.4 软件将上述扫描图像 转化为信号值. 根据探针信号值的 $P$ 值确定基因表达 $(P<0.05)$ 、临界表达 $(0.05<P<0.065)$ 和不表达 $(P>0.065)$. 然后对每张芯片的信号值做均一化处理，用实验组 的均一化值比对照组的均一化值得出某一基因的相 对值, 当相对值 $\geq$ 对照 3 倍时, 视为基因发生有意表 达上调, 当相对值 $\leqslant$ 对照 0.33 时, 视为基因发生有意 
表达下调，当相对值在 2.99 0.33 之间时，视为基因 未发生有意表达变化. 为减少芯片分析误差, 每个时 间点的再生肝分离细胞均重复检测 3 次, 将 3 次相对 值的平均值作为有效实验值. 最后用 GeneMath ${ }^{[24]}$, GeneSpring $^{[25]}$, Microsoft Excel ${ }^{[26]}$, Pathway Studio

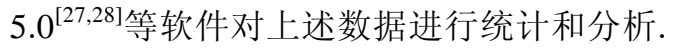

\subsection{RT-PCR}

根据 GenBank 登录的 HC, BEC, OC, HSC, SEC, $\mathrm{KC}, \mathrm{LC}$ 和 DC 标志基因 $g 6 p c, g g t 1, o c 2, g f a p, c d 14, l y z$, $c d 56, c d 86$ 和内参 $\beta$-actin 的序列号 $\mathrm{U}_{07993}, \mathrm{NM}_{-}$ 053840, BG671896, NM_017009, NM_021744, L12458, NM_031521，NM_020081 和 NM_031144, 用 primer express 2.0 软件设计它们的引物和探针, 并由上海基 康生物公司合成.

取本文 1.2 小节中的总 RNA $4 \mu \mathrm{g}$ 分别与 $4 \mu \mathrm{L}$

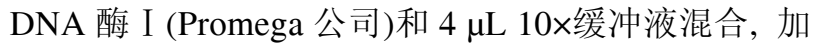
$1 \mu \mathrm{L}$ 无核酸酶纯水补足 $10 \mu \mathrm{L}$, 混匀后, $37^{\circ} \mathrm{C}$ 孵育 30 $\min$. 加 $1 \mu \mathrm{L}$ 反应终止液, 于 $65^{\circ} \mathrm{C}$ 孵育 $10 \mathrm{~min}$, 得到 无 DNA 污染的 RNA; 取 $0.2 \mathrm{~mL}$ EP 管, 加入 $5.5 \mu \mathrm{L}$ 制备好的 RNA 和 $4.4 \mu \mathrm{L}$ 无核酸酶纯水, $70^{\circ} \mathrm{C}$ 睬育 10 $\min$, 冰浴 $5 \mathrm{~min}$, 然后加入 $10.1 \mu \mathrm{L}$ 含高浓度反转录 酶和 RNA 酶抑制剂的混合液; 用随机引物反转录时, 分别于 $25^{\circ} \mathrm{C}$ 孵育 $10 \mathrm{~min}, 42^{\circ} \mathrm{C}$ 孵育 $60 \mathrm{~min}$, 得到单链 cDNA; 将上步合成的 cDNA 稀释成 5 个梯度(每个梯 度相差 5 倍), 将它们在不同引物浓度和退火温度下 进行定量 PCR 反应, 在合适的反应条件下, 选择相 关系数 $>0.99$ 、扩增效率在 $0.8 \sim 1.2$ 之间的曲线作为标 准曲线.

用上述制备的 cDNA 和确定的扩增条件, 在 Rotor Gene 3000 PCR 仪(Corbett Research 公司)上扩 增 $g 6 p c, g g t 1, o c 2, g f a p, c d 14, l y z, c d 56, c d 86$, 每个基 因均做 3 个平行重复实验. 本实验选用的内参为 $\beta$-actin, 用双标准曲线法 ${ }^{[29]}$ 分析 PCR 结果.

\section{5 肝再生相关基因的确认}

根据 geneontology 网站的生理活动分类 ${ }^{[24]}$, 将 缺血反应输入 NCBI 和 RGD 等网站查找大鼠、小 鼠和人的有关基因, 并根据 GENMAPP, KEGG, BIOCARTA $^{[24,25,27,30,31]}$ 等网站的生理活动途径图汇总 上述基因. 然后查阅相关文献资料对上述基因进行 再确认. 将部分肝切除后至少一个时间点的表达变
化 $\geq$ 对照 3 倍(上调)或 $\leq$ 对照 0.33(下调)、部分肝切除 组与手术对照组差异显著 $(P \leq 0.05)$ 或极显著 $(P \leq 0.01)$, 且同一时间点 3 次芯片检验结果趋势相同的基因视 为缺血反应肝再生相关基因.

\section{2 结果}

\section{1 再生肝 8 种细胞分离纯度的鉴定}

取 PH 后恢复 $0,2,6,12,24,30,36,72,120$ 和 168 $\mathrm{h}$ 等时间点分离的 HC, BEC, OC, HSC, SEC, KC, LC 和 $\mathrm{DC}$, 滴片后进行细胞免疫组化检测. 结果表明, 再生肝 8 种细胞分散良好, 呈卵圆形或圆型, 核小而 圆位于细胞中央，阳性细胞比率均在 $95 \%$ 以上，可用 于芯片检测(图 1).

\subsection{Rat Genome 2302.0 芯片的检测结果可靠性}

取 PH 后恢复 $0,2,6,12,24,30,36,72,120$ 和 168 $h$ 等时间点分离的 HC, BEC, OC, HSC, SEC, KC, PC 和 DC, 用 RT-PCR 和 Rat Genome 2302.0 芯片检测 它们的标志基因 $g 6 p c, g g t 1, o c 2, g f a p, c d 14, l y z, c d 56$, $c d 86$ 等的表达情况. 结果表明, 在两者中 $g g t 1$ 和 $c d 14$ 均表达上调, $g 6 p c, g f a p$ 和 $c d 86$ 均表达下调, $o c 2$, $l y z$ 和 $c d 56$ 均未发生有意表达变化. 上述基因的表达 趋势均与 RT-PCR 的检测结果无显著差异, 表明芯片 结果可靠(图 2).

\section{3 缺血反应相关基因在大鼠再生肝 8 种细胞中 起始表达及总表达情况}

NCBI, AMIGO, BIOCARTA, KEGG, RGD 和 MGI 等网站资料表明, 215 个基因与缺血反应相关. Rat Genome 2302.0 芯片资料表明，该芯片含上述的 210 个基因. 用该芯片检测大鼠再生肝 8 种细胞中的 基因表达谱表明, 有 108 个缺血反应相关基因发生有 意表达, 在 HC, BEC, DC, KC, SEC, HSC, LC 及 OC 中发生有意变化的基因分别为 $27,50,38,40,24,39$, 13 和 23 个. 相应的表达上调、下调和上/下调(至少在 肝再生的一个时间点上调和一个时间点下调)的基因 数分别为 23,3 和 $1,20,17$ 和 $12,16,17$ 和 $5,28,9$ 和 $3,18,5$ 和 $1,15,21$ 和 4, 7,6 和 $0,19,2$ 和 2 . 它们的 上调范围为对照的 3 1209 倍, 下调范围为对照的 3 351 倍(表 1). 再生肝 8 种细胞 HC, BEC, DC, KC, SEC, HSC, LC 及 OC 中基因起始表达上调和下调基 
if
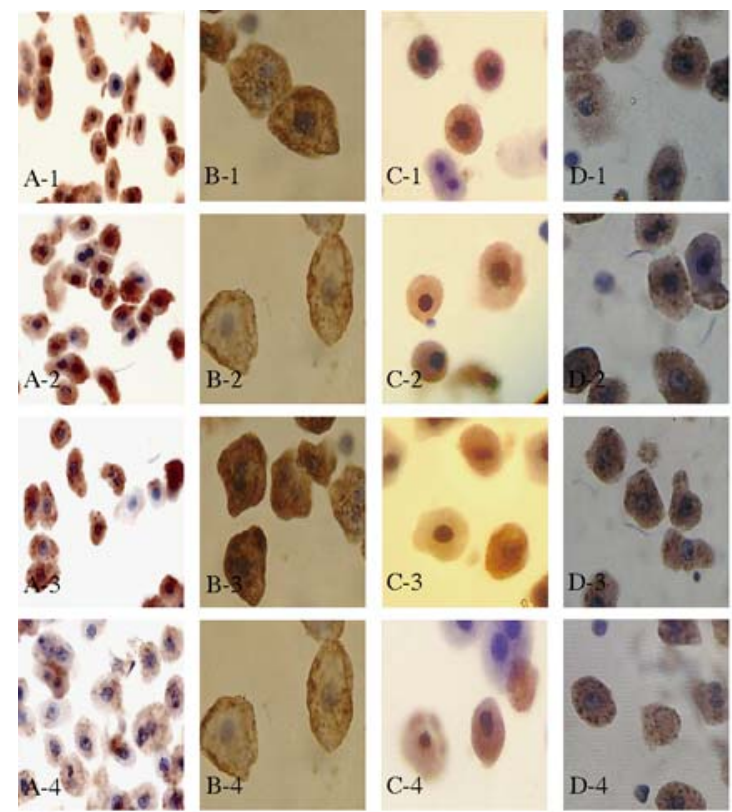

o. 08

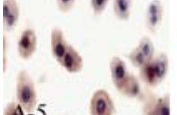

$45,0,15$

है है,

\section{6. $x^{2}$}

$\mathrm{A}-6,8+19$
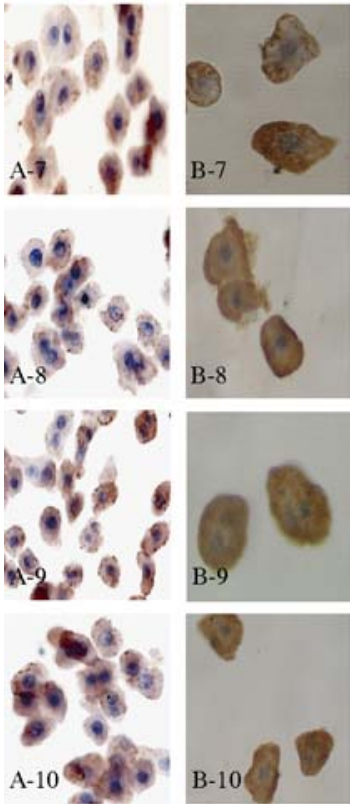
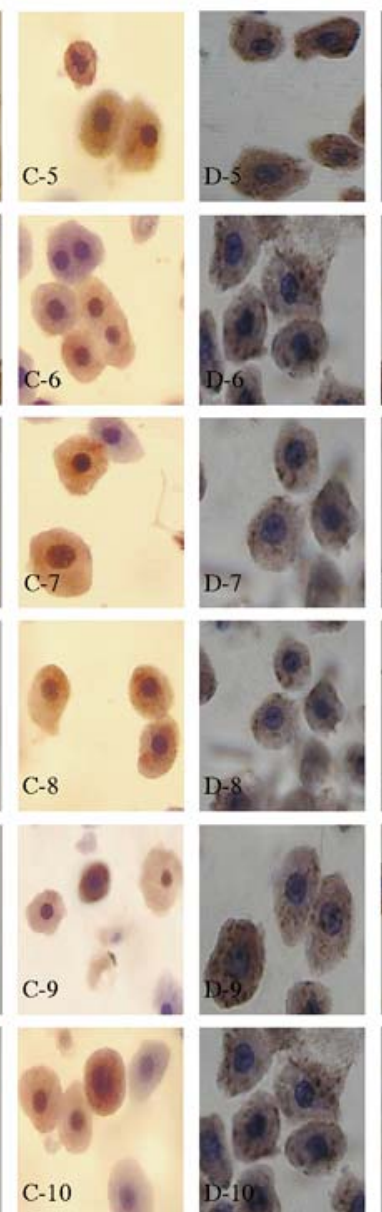

图 1 大鼠再生肝 8 种细胞的鉴定 $(40 x)$
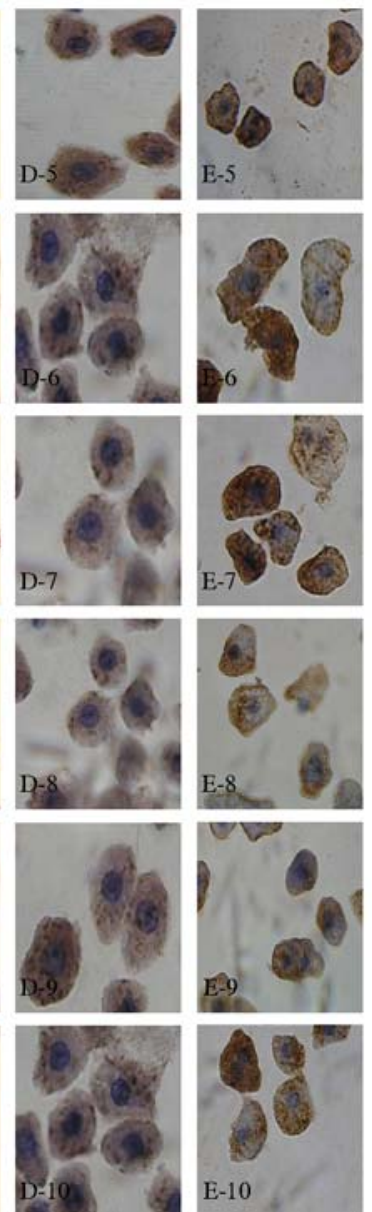
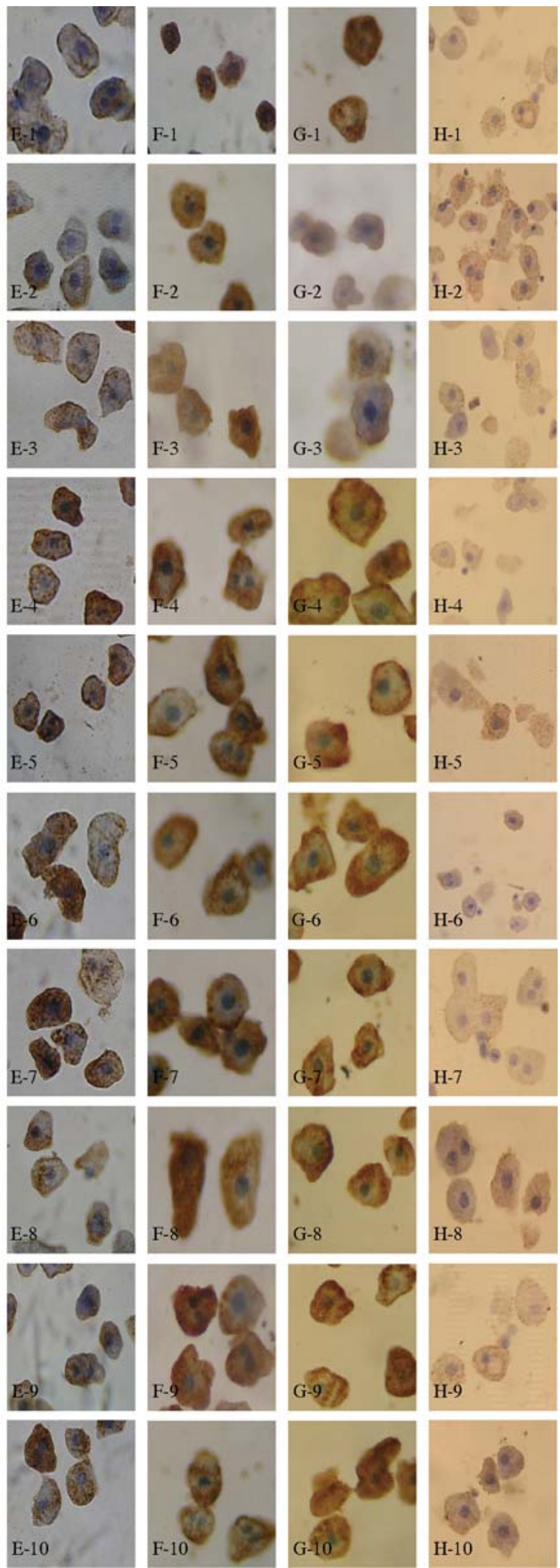

1 10 示大鼠 PH 后 0,2, 6, 12,24,30,36,72, 120 和 168 h; A H 示 HC, BEC, OC, HSC, SEC, KC, LC, DC 分别滴加一抗 ALB, CK18, OC2, DES, CD14, LYZ, CD8, CD86 后的免疫组化结果 
因数分别为 23 和 4,23 和 26,21 和 17,29 和 11,18 和 6,19 和 21,7 和 6,20 和 3(图 3(A)). 它们的总上调 次数与总下调次数分别为 110 和 8,90 和 78,87 和 52 , 123 和 38, 57 和 10,55 和 57,27 和 20, 59 和 7(图 3(A)). $\mathrm{KC}, \mathrm{BEC}, \mathrm{SEC}, \mathrm{HC}, \mathrm{HSC}, \mathrm{OC}$ 及 $\mathrm{LC}$ 的上调和下调基 因数分别为 12 和 8,4 和 0,8 和 13,6 和 1,12 和 0,9
和 5, 5 和 1,4 和 3(图 3(B)). 通过对 8 种细胞的聚类 分析, 发现: (1) BEC, HSC, DC 的缺血反应相关基因 具有表达的相似形; (2) 在不同细胞中表达的同一基 因表达趋势近似; (3) 8 种细胞中都是表达上调基因占 优势，但 BEC 中表达变化 10 倍以上的下调基因大于 上调基因.
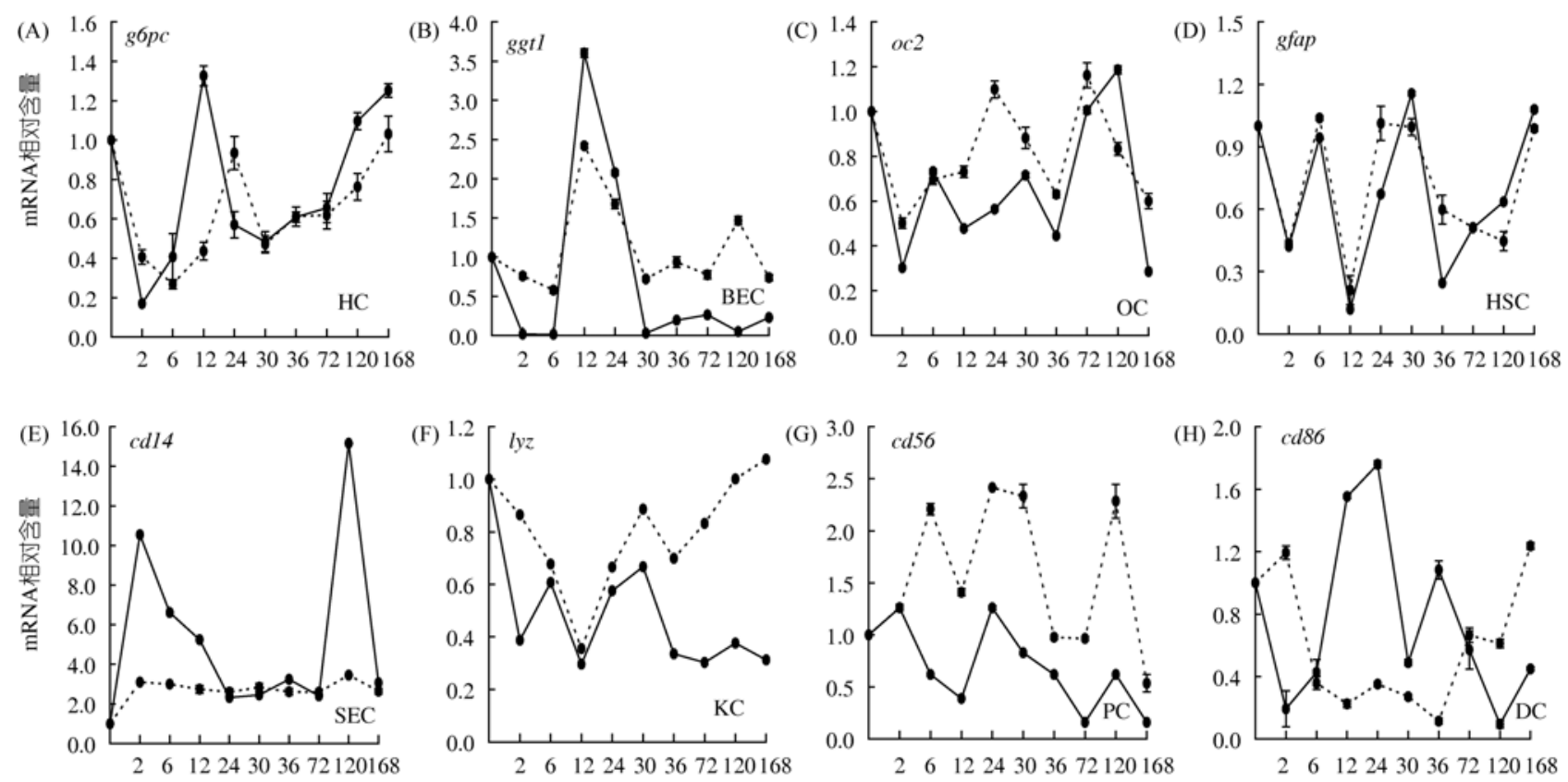

部分肝切除后恢复时间/h

图 2 再生肝 8 种细胞的标志基因 mRNA 含量变化

实线示 RT-PCR 检测结果; 虚线示 Rat Genome 2302.0 芯片检测结果
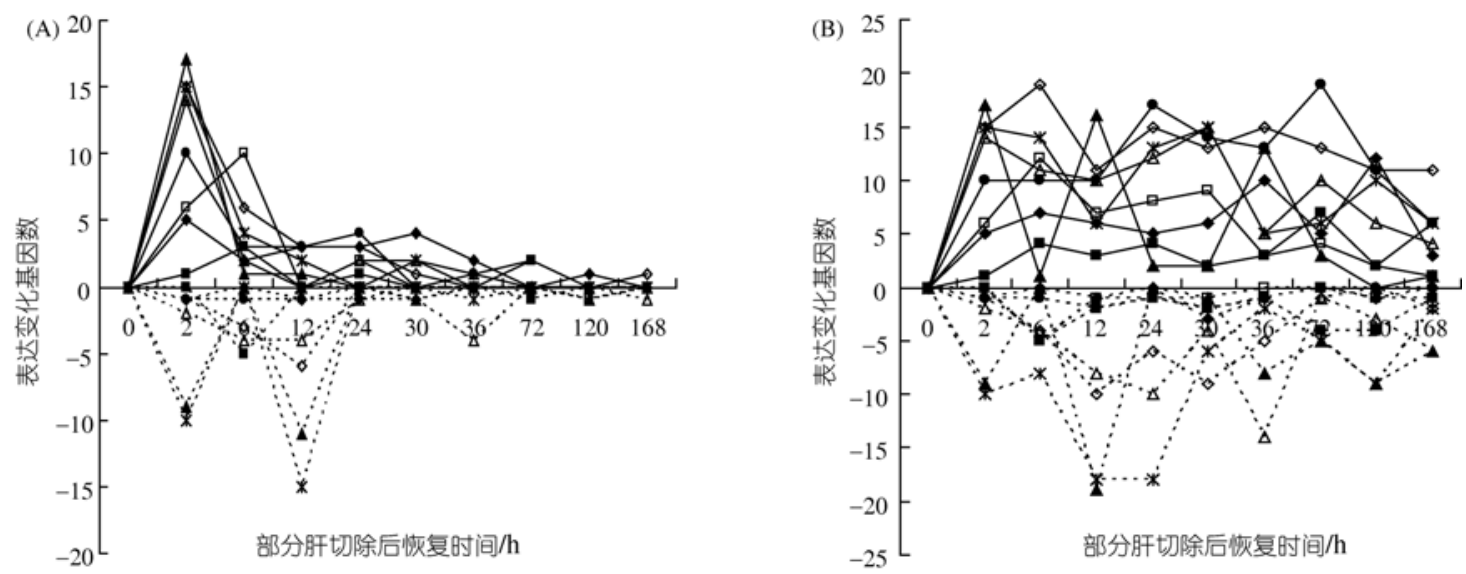

图 3 缺血反应相关基因在大鼠再生肝 8 种细胞中起始表达及总表达情况

（A）基因起始表达情况；B）基因总表达情况. 实线示表达上调基因; 虚线示表达下调基因. ・示 HC 中与缺血相关基因; *示 BEC 中与缺 血相关基因; $\triangle$ 示 DC 中与缺血相关基因; $\diamond$ 示 $\mathrm{KC}$ 中与缺血相关基因; 口示 SEC 中与缺血相关基因; $\Delta$ 示 HSC 中与缺血相关基因; - 示 LC 中与缺血相关基因;

示 OC 中与缺血相关基因 
表 1 缺血反应相关基因在大鼠再生肝 8 种细胞中的表达丰度

\begin{tabular}{|c|c|c|c|c|c|c|c|c|c|}
\hline \multirow{2}{*}{ 基因名称 } & \multirow{2}{*}{ 缩写 } & \multicolumn{8}{|c|}{ 表达丰度 } \\
\hline & & $\mathrm{HC}$ & BEC & $\mathrm{DC}$ & $\mathrm{KC}$ & SEC & HSC & $\mathrm{LC}$ & $\mathrm{OC}$ \\
\hline adenosine A3 receptor & Adora3 & & 0.21 & & & & & & \\
\hline angiotensinogen & Agt & & 0.03 & 10.21 & 5.09 & 61.51 & $17.16,0.1$ & & \\
\hline angiotensin II receptor, type 1 (AT1A) & Agtrla & 0.23 & & 0.14 & & & & & \\
\hline angiogenin, ribonuclease A family, member 1 & Ang1 & 0.27 & 0.03 & 0.08 & & 6.47 & 6.12 & 0.04 & 0.29 \\
\hline angiopoietin-like 4 & Angptl4 & & & 0.13 & 4.82 & 13.67 & 12.57 & 0.09 & \\
\hline apolipoprotein $E$ & Apoe & & 0.01 & 0.25 & & & & 0.21 & \\
\hline amyloid beta (A4) precursor protein & App & & 5.02 & 0.29 & & & & & \\
\hline aquaporin 4 & Aqp4 & 6.31 & & & & & & & \\
\hline bradykinin receptor $B 1$ & $B d k r b 1$ & & & & & 0.10 & & & \\
\hline brain derived neurotrophic factor & $B d n f$ & & & & 19.69 & & & & 6.45 \\
\hline BH3 interacting domain death agonist & Bid & & $4.37,0.11$ & 0.14 & & & & & \\
\hline baculoviral IAP repeat-containing 4 & Birc4 & & & & & & 3.90 & & \\
\hline BCL2/adenovirus E1B $19 \mathrm{kD}$-interacting protein 3 & Bnip3 & & & & & & 4.18 & & \\
\hline chemokine ( $C$ - $C$ motif) ligand 2 & $C c l 2$ & 21.05 & 30.85 & 5.40 & 7.08 & 7.45 & & 8.88 & 9.45 \\
\hline cyclin D1 & Ccnd1 & 8.37 & 6.44 & & 4.90 & & & & 4.33 \\
\hline $\operatorname{cyclin} E$ & Ccnel & 24.20 & & 5.58 & 6.16 & & & & 4.92 \\
\hline CD44 antigen & $C d 44$ & & & & $3.18,0.22$ & & & 5.21 & \\
\hline conserved helix-loop-helix ubiquitous kinase (predicted) & Chuk & & 5.39 & & & & & & \\
\hline clusterin & $\mathrm{Clu}$ & & & & & & 9.87 & & \\
\hline crystallin, alpha $B$ & Cryab & & 11.74 & & & & & & \\
\hline chemokine ( $C$-X3-C motif) ligand 1 & Cx3cll & & & & 0.11 & 0.22 & & & \\
\hline chemokine ( $C$ - $X$-C motif) ligand 2 & Cxcl2 & & 6.34 & 98.22 & 9.85 & 8.93 & 0.10 & 10.55 & \\
\hline cytochrome $b-245$, alpha polypeptide & $C y b a$ & & 0.13 & & 0.31 & & & & \\
\hline cytochrome $b-245$, beta polypeptide & $C y b b$ & & & 0.07 & 0.22 & & 0.10 & & 3.39 \\
\hline cysteine rich protein 61 & Cyr61 & & 14.76 & & 6.98 & & & & \\
\hline decay accelarating factor 1 & Daf1 & & & 4.16 & & & & & \\
\hline DNA-damage-inducible transcript 4 & Ddit4 & & & 5.10 & & & 0.29 & & \\
\hline discs, large homolog 4 (Drosophila) & $\operatorname{Dlgh} 4$ & & $3.11,0.25$ & & & & & & \\
\hline E2F transcription factor 1 & $E 2 f 1$ & 6.90 & & & & & & & 3.89 \\
\hline endothelin receptor type $B$ & $E d n r b$ & 18.49 & & 0.20 & 11.36 & & & & $4.47,0.27$ \\
\hline epidermal growth factor & Egf & 0.18 & & & & & & & \\
\hline endonuclease $G$ & Endog & & 0.09 & & & & & & \\
\hline ectonucleoside triphosphate diphosphohydrolase 1 & Entpdl & 7.15 & & 0.19 & 0.14 & & & & \\
\hline Eph receptor $B 1$ & Ephbl & 7.28 & & & & & & & \\
\hline coagulation factor II & $F 2$ & & 0.02 & & & 5.95 & $6.26,0.29$ & 0.07 & \\
\hline coagulation factor II(thrombin) receptor & $F 2 r$ & & & & & & 0.25 & & \\
\hline coagulation factor II(thrombin) receptor-like 2 & $F 2 r l 2$ & & 0.20 & & & & & & \\
\hline coagulation factor 5 & F5 & & 0.11 & $3.6,0.3$ & & 6.08 & 10.62 & 0.26 & \\
\hline FBJ murine osteosarcoma viral oncogene homolog & Fos & 14.96 & $5.26,0.14$ & $3.3,0.1$ & & 6.04 & & & \\
\hline fyn proto-oncogene & Fyn & 9.87 & & 0.12 & 0.16 & 0.15 & 0.11 & & \\
\hline glutamate receptor, ionotropic, AMPA1 (alpha 1) & Grial & & $4.56,0.15$ & & & & & & \\
\hline glutamate receptor, ionotropic, AMPA2 & Gria2 & & & & 8.75 & & & & \\
\hline glutamate receptor, ionotropic, AMPA3 (alpha 3) & Gria3 & 16.57 & & 17.39 & 9.21 & & 13.25 & & 12.84 \\
\hline glutamate receptor, ionotropic, $N$-methyl D-aspartate $2 A$ & Grin $2 a$ & & 15.11 & & & & & & \\
\hline hepatocyte growth factor & $H g f$ & 18.65 & & & & & & & \\
\hline heme oxygenase (decycling) 1 & Hmoxl & & 5.72 & & & 4.72 & & & \\
\hline homeobox only domain & Hod & & & 0.09 & 0.14 & 0.26 & 0.16 & & \\
\hline haptoglobin & $H p$ & & 0.003 & & & 5.79 & & & \\
\hline heat shock $70 k D$ protein $1 A$ & Hspala & & & 7.91 & 4.04 & & & & 3.92 \\
\hline heat shock $22 k D$ protein 8 & $H s p b 8$ & & 5.72 & & 3.55 & 9.79 & 0.19 & & \\
\hline heat shock $10 \mathrm{kD}$ protein 1 (chaperonin 10$)$ & Hspe1 & & 0.05 & & & & & & \\
\hline hypoxia up-regulated 1 & Hyoul & & & & 3.78 & & & & \\
\hline intercellular adhesion molecule 1 & Icam1 & & $3.09,0.10$ & & & & & & \\
\hline interleukin 1 beta & $I l 1 b$ & & 4.60 & $4.7,0.1$ & & $4.07,0.27$ & & 5.15 & \\
\hline
\end{tabular}




\begin{tabular}{|c|c|c|c|c|c|c|c|c|c|}
\hline \multirow{2}{*}{ 基因名称 } & \multirow{2}{*}{ 缩写 } & \multicolumn{8}{|c|}{ 表达丰度 } \\
\hline & & $\mathrm{HC}$ & BEC & $\mathrm{DC}$ & KC & SEC & HSC & LC & OC \\
\hline interleukin 6 & Il6 & & 4.66 & 24.57 & 9.75 & & 15.22 & & 11.64 \\
\hline Jun oncogene & Jun & & & & & 3.71 & & & \\
\hline kinase insert domain protein receptor & $K d r$ & $5.35,0.12$ & 0.03 & 0.03 & & 0.12 & 0.04 & & 0.15 \\
\hline lipocalin 2 & Lcn2 & 101.11 & 5.15 & 1209.189 & $9.21,0.18$ & 11.28 & $26.98,0.11$ & & 44.70 \\
\hline leptin & Lep & & $3.95,0.04$ & & & & & & \\
\hline lectin, galactose binding, soluble 3 & Lgals3 & & $3.63,0.08$ & 0.18 & & & 0.18 & & \\
\hline myelin-associated glycoprotein & Mag & & $4.06,0.19$ & & & & & & \\
\hline microtubule-associated protein tau & Mapt & & & & 5.74 & & & & \\
\hline met proto-oncogene & Met & & $4.26,0.11$ & & & & & & \\
\hline milk fat globule-EGF factor 8 protein & Mfge8 & & & & & & 0.13 & & \\
\hline matrix metallopeptidase 14 (membrane-inserted) & Mmp14 & & & & 4.69 & & & & \\
\hline matrix metallopeptidase 9 & Mmp9 & & & 20.61 & 5.52 & & 0.20 & & 4.92 \\
\hline myelocytomatosis viral oncogene homolog (avian) & Myc & 5.43 & 7.29 & & 3.85 & & & & 4.05 \\
\hline nitric oxide synthase 1 , neuronal & Nos1 & & 0.18 & & & & & & \\
\hline nitric oxide synthase 2 , inducible & Nos2 & & & 12.20 & & & & & \\
\hline nitric oxide synthase 3 , endothelial cell & Nos 3 & & & & 7.91 & & & & \\
\hline neuropeptide $Y$ & Npy & 12.51 & & & & & & & 9.02 \\
\hline nuclear receptor subfamily 4, group A, member 2 & $N r 4 a 2$ & & & 10.22 & & & & & \\
\hline neuregulin 1 & $\mathrm{Nrg} 1$ & 6.43 & & & 11.66 & & 6.57 & & 4.50 \\
\hline neurotrophin 3 & Ntf3 & & & & 4.07 & & 21.88 & & \\
\hline proliferating cell nuclear antigen & Pcna & & 5.49 & & & & 0.26 & & \\
\hline phospholipase A2, group IIA (platelets, synovial fluid) & Pla2g2a & 151.14 & 29.59 & $22.4,0.2$ & & 7.23 & & 23.58 & 15.94 \\
\hline plasminogen activator, tissue & Plat & 28.49 & & & 7.93 & & & & 7.66 \\
\hline plasminogen activator, urokinase & Plau & & & 0.09 & & & 0.11 & & \\
\hline plasminogen activator, urokinase receptor & Plaur & 12.83 & & & & 10.83 & & & \\
\hline phospholamban & $P \ln$ & 17.56 & & & & & & & \\
\hline paraoxonase 1 & Pon1 & & & & & & 3.96 & & \\
\hline paraoxonase 2 & Pon2 & & 0.18 & & & & & & \\
\hline protein kinase, AMP-activated, alpha 2 catalytic subunit & Prkaa2 & & & $13.3,0.2$ & & & $6.50,0.21$ & 0.10 & \\
\hline protein kinase $C$, delta & Prkcd & & & & & & 0.28 & & \\
\hline protein kinase $C$, epsilon & Prkce & & & & & & 10.30 & & \\
\hline prion protein & Prnp & & 6.50 & & & & & & \\
\hline patched homolog 1 (Drosophila) & Ptchl & & $11.91,0.16$ & & & & 0.16 & & \\
\hline phosphatase and tensin homolog & Pten & & 0.12 & & & & & & \\
\hline prostaglandin E receptor 4 (subtype EP4) & Ptger4 & & & & $3.79,0.31$ & & & & \\
\hline prostaglandin-endoperoxide synthase 2 & Ptgs 2 & & 4.13 & 26.97 & 6.60 & & & & 8.74 \\
\hline serine (or cysteine) peptidase inhibitor, clade E, member 1 & Ptgs 2 & & & & & & & 37.74 & \\
\hline RNA binding motif protein 3 & $\operatorname{Rbm} 3$ & 8.27 & $6.76,0.24$ & & & & & & \\
\hline ribosomal protein $S 9$ & Rps9 & & $4.11,0.12$ & & & & & & \\
\hline serine (or cysteine) peptidase inhibitor, clade E, member 1 & Serpine1 & 22.52 & & 11.91 & 33.20 & 11.65 & 46.88 & & 72.32 \\
\hline serum/glucocorticoid regulated kinase & $S g k$ & 4.32 & & & & & & & \\
\hline Src homology 2 domain-containing transforming protein C1 & Shcl & & 0.07 & & & & & & \\
\hline solute carrier family 23 (nucleobase transporters), member 2 & Slc23a2 & & 10.02 & & & & & & \\
\hline solute carrier family 38, member 3 & Slc38a3 & & 0.06 & & & 17.35 & 9.27 & & \\
\hline superoxide dismutase 1 & Sod1 & & 0.003 & & & & & & \\
\hline superoxide dismutase 2, mitochondrial & $\operatorname{Sod} 2$ & & & & & & 3.75 & & \\
\hline signal transducer and activator of transcription 4 & Stat4 & & & & 0.14 & & 0.14 & & \\
\hline transforming growth factor, beta 1 & $T g f b 1$ & & & 0.03 & & & 0.10 & & \\
\hline transforming growth factor, beta receptor II & $T g f b r 2$ & & & & & & 0.10 & & \\
\hline thrombomodulin & Thbd & & 12.49 & 4.93 & 8.14 & 5.21 & 0.19 & & 9.46 \\
\hline toll-like receptor 2 & $T l r 2$ & & & 0.06 & 0.19 & & & & \\
\hline toll-like receptor 4 & Tlr4 & & & 0.22 & 0.11 & & 0.11 & & \\
\hline tumor necrosis factor (TNF superfamily, member 2) & $\operatorname{Tnf}$ & & & & 6.21 & & & 11.684 & $4.96,0.13$ \\
\hline uracil-DNA glycosylase & Ung & & & & 3.74 & & & & \\
\hline
\end{tabular}




\section{4 缺血反应相关基因在大鼠再生肝 8 种细胞中 表达的聚类分析}

根据肝再生中基因表达的时间相关性，将上述 基因分为 12 与 $24 \mathrm{~h}, 2$ 与 $36 \mathrm{~h}, 6$ 与 $30 \mathrm{~h}, 72$ 与 $120 \mathrm{~h}$, $168 \mathrm{~h}$ 等 5 组, 表达上调和下调的基因数分别为 145 和 98,150 和 56,154 和 55,121 和 43, 38 和 18 (图 4(A)). 60 个基因的上调表达丰度大于或等于对照的 10 倍, 31 个基因的下调表达丰度小于或等于对照的 10 倍. 其中 DC, KC, BEC, SEC, HC, HSC, OC 及 LC 的上调 和下调基因数分别为 12 和 8,4 和 0,8 和 13,6 和 1,12 和 0,9 和 5,5 和 1,4 和 3 (图 4(B)). 通过对 8 种细胞 的聚类分析, 发现: (1) BEC, HSC, DC 的缺血反应相 关基因具有表达的相似形; (2) 在不同细胞中表达的 同一基因表达趋势近似; (3) 8 种细胞中都是表达上调 基因占优势, 但 $\mathrm{BEC}$ 中表达变化 10 倍以上的下调基 因大于上调基因.

\section{5 缺血反应相关基因在大鼠再生肝 8 种细胞中 的互作关系}

为探讨缺血时再生肝 8 种细胞的互作关系, 用 pathway studio 5.0 软件内置的 ResnetCore 1.2 数据库, 以基因为节点, 基因间的相互关系为连线, 构建各细 胞的基因网络调控图. 分析表明, 几种细胞间存在相 互作用, 如只在 HSC 中表达的基因能作用于 DC, BEC 中的 APP, DC, BEC 中的 FOS 以及作用于 DC, $\mathrm{BEC}, \mathrm{OC}, \mathrm{KC}$ 中的 IL6; 只在 DC 中表达的基因能作 用于 $\mathrm{BEC}$ 中的特殊基因 $I C A M I$ 及 $\mathrm{KC}, \mathrm{SEC}$ 中的 $F Y N$; 只在 $\mathrm{KC}$ 中表达的基因能作用于 $\mathrm{HSC}$ 中的特殊基因 $F 2 R$; 只在 $\mathrm{HC}$ 中表达的基因能作用于 $\mathrm{DC}, \mathrm{BEC}$ 中的 $F O S$; 只在 $\mathrm{BEC}$ 中表达的基因能作用于 $\mathrm{KC}, \mathrm{SEC}$ 中的 $F Y N, \mathrm{KC}$ 中的特殊基因 NOS3 以及 $\mathrm{HSC}$ 中的特殊基 因 $F 2 R$ (图 5). 由此可见, 这些基因虽然在不同细胞 中表达, 但它们能通过网络互作参与其他细胞的基 因表达变化. 几种细胞既单独作用又互相配合, 从而 推动肝再生进行.

\section{3 讨论}

部分肝切除带来的缺血损伤与肝脏移植及肝脏 病理性切除对肝脏造成缺血再灌注损伤不完全相同, 它对肝再生的进程有何作用尚不了解. 以往的研究
多局限在组织水平及单种肝脏细胞水平的研究

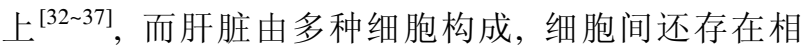
互作用关系，只有分离出不同的肝脏细胞才能更全 面地了解 PH 后缺血反应对肝再生的影响。

本研究表明, 肝再生中的缺血反应基因大多在 2 $\mathrm{h}$ 被激发进行初始表达且上调变化占绝对优势，对于 局部缺血且原有血流方向发生改变的启动期再生肝 来说, 首先要调整血流量、稳定血压, 其次进行术后 结扎部位的伤口愈合，促进这些部位的血液凝固及 细胞凋亡, 并激发与此相关的一些信号通路. 因此,

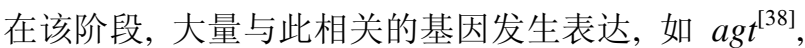
$\operatorname{agtrl} a^{[39]}$, ptgs $2^{[40]}, \operatorname{cyr} 61^{[41]}, k d r^{[42]}$, serpine $1^{[43]}, f 2^{[44]}$ 等. 进入进展期后, 在 $12 \mathrm{~h}$ 处基因起始表达又达到一 个高峰, 虽然在此期间进行初始表达基因的功能与 启动阶段类似，但大都已变为下调表达或进行负调 控的上调表达, 如 $c y b a^{[45]}, n p y^{[46]}$ 等. $12 \mathrm{~h}$ 之后, 虽然 也有基因进行初始表达, 但数量不多. 说明缺血反应 对肝再生的影响主要发生在启动阶段及进展阶段 初期.

除了细胞之间共同表达的基因外，还有一些基 因只在一种细胞中发生表达变化. HC 中的基因与促 进细胞增殖、激活信号通路、细胞调亡有关, 如 $h g f^{[47]}$, $e g f^{[48], e p h b 1}{ }^{[49]}$ 等, 尤其是 $a q p 4$ 能通过水通道解决 缺血后局部组织的水肿 ${ }^{[50]}$, 在 $2 \mathrm{~h}$ 起始上调表达, 并 在 6,30，72，120,168 都进行上调表达. BEC 中基因 与缺血应激、细胞增殖、血液凝固、细胞凋亡、炎症

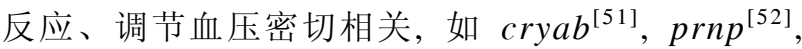
$s l c 23 a 2^{[53]}$ 等. 此外, 还有一些以往研究显示只与神 经缺血反应有关的基因, 如 $\operatorname{grin} 2 a^{[54]}$, adora $3^{[55]}$, $g r i a l^{[56]}, m a g^{[57]}, d l g h 4^{[58]}$ 等, 可能在再生肝的胆管细 胞内有缺血应激的功能, 但具体作用仍需进一步 研究. DC 中与调控血压、促进细胞生长、抑制免疫

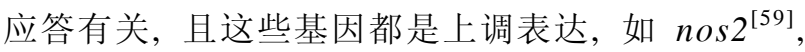
$n r 4 a 2^{[60]}, d a f I^{[61]}$ 等. $\mathrm{KC}$ 中的基因与血管再生、炎症反 应、DNA 修复、阻滞细胞周期、神经递质传导有关， 且几乎全为上调表达, 如 $g r i a 2^{[62]}, n o s 3^{[63]}, u n g^{[64]}$ 等. $^{6}$. SEC 中的基因与血管新生、降低血压有关, 如 $j u n^{[65]}$ 和 $b d k r b 1^{[66]}$, 前者为上调, 后者为下调, 说明缺血时 需要收缩血管稳定血压. HSC 中的基因与细胞凋亡、 调亡细胞清除、脂类代谢、血液凝固、炎症反应等功 能有关, 如 bnip $3^{[67]}, \operatorname{sod} 2^{[68]}, \operatorname{cl} u^{[69]}$ 等; 而参与血液凝 固与炎症反应的都为下调基因, 如 $f 2 r^{[70]}, t g f b r 2^{[71]}$ 等; 
(A)

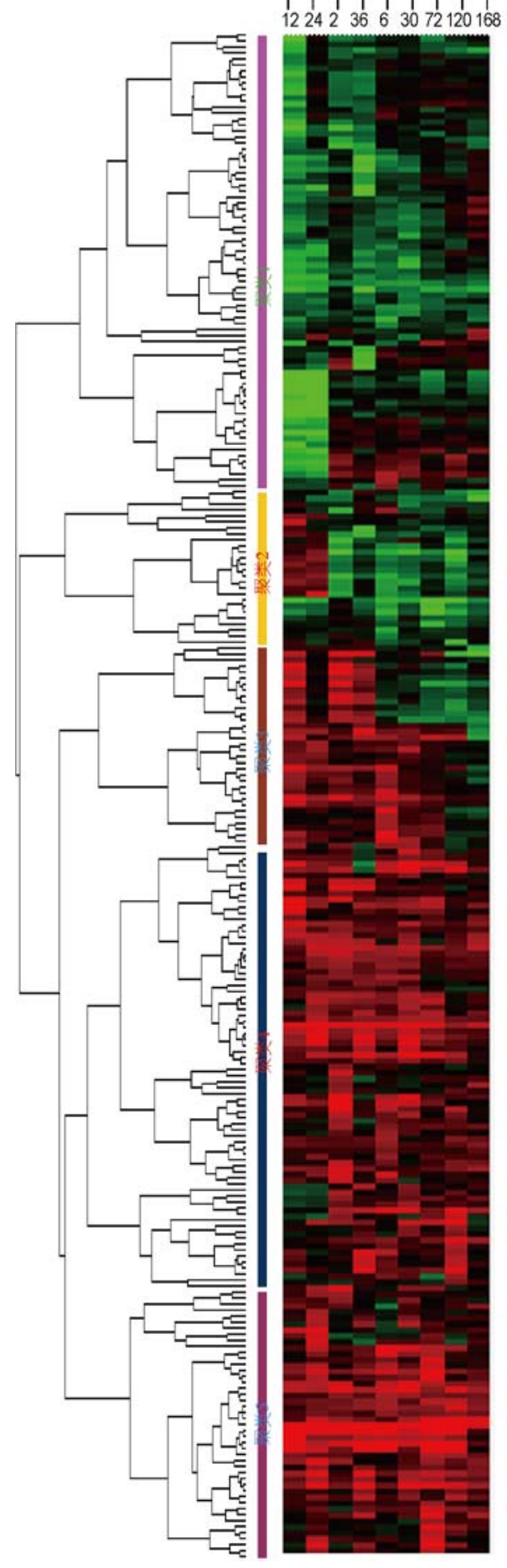

(B)
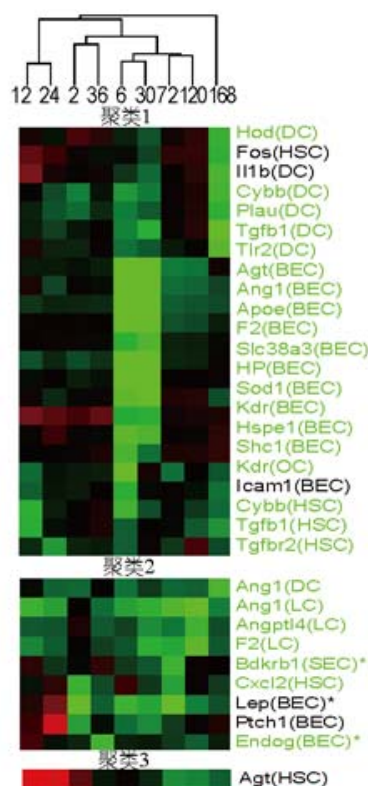

Ang1(DC

Angptl4(LC)

B2(LC)

Cxel2(HSC)

Ptch1 (BEC)

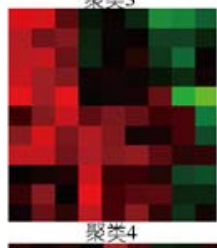

gt(HSC)

(HSC)

Griaz(HSC)

Len2(HSC)
Prkaa2(DC)

Agt(DC)

Plaur(HC)

Angptit(SEC)

Serpine1(SEC)

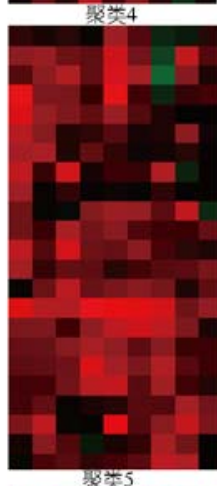

Nr4a2(DC)

Mmp9(DC)

Cxel2(DC)

$116(\mathrm{DC})$

Cyr61(BEC)

Thbd(BEC)
N+t3(HSC)

Ntf3(HSC)
Prkce (HSC),

Gria3(DC)

Serpine1(DC

Serpine1 (HC)

Plaur(SEC)

116 (HSC)
Serpine1 (KO)

Cel2(HC)

Nrg1(KC)

Cene1(HO)

Ednrb(KC)

Pla2g2a(BEC

$16(\mathrm{OC})$
Pla $292 \mathrm{a}(\mathrm{OCC})$

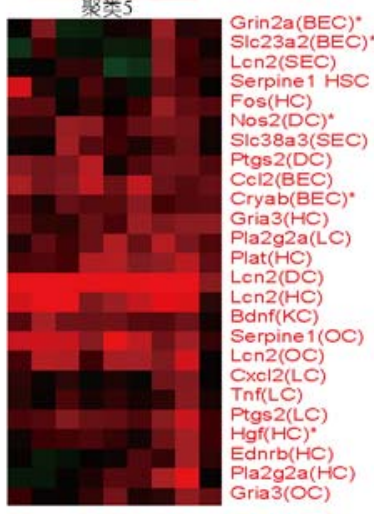

图 4 大鼠再生肝 8 种细胞中的缺血反应基因表达的相似性聚类和时间相关性聚类

（A）总聚类图; (B) 表达变化 $\geq 10$ 倍的基因聚类图. 红色示表达上调基因, 绿色示表达下调基因, 黑色示未发生有意变化基因, * 示只在该细胞中表达的基因; 左侧树为基因表达趋势聚类，上方树为时间相关性聚类 


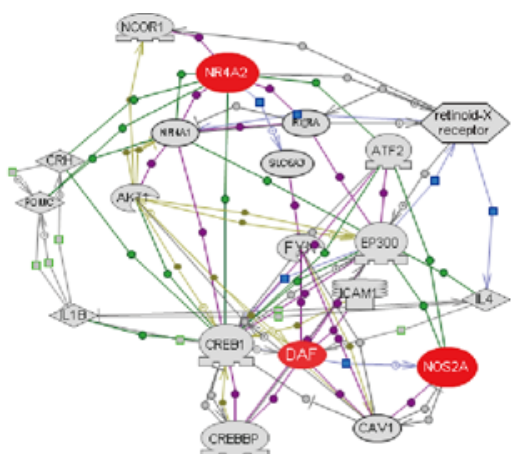

(A) $\mathrm{DC}$

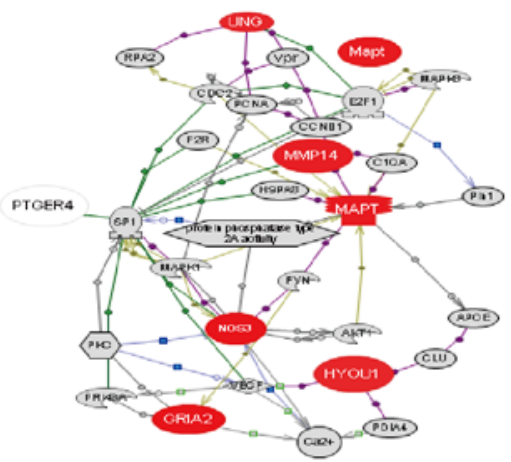

(C) $\mathrm{KC}$

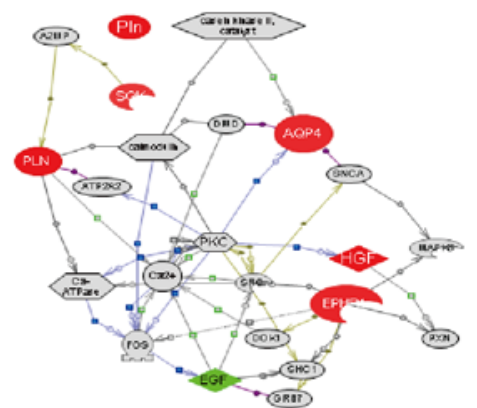

(E) $\mathrm{HC}$

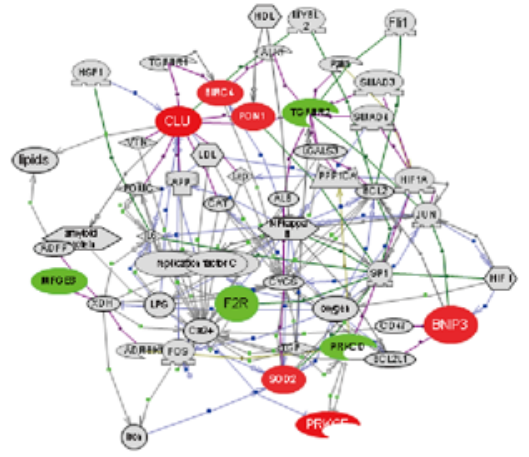

(B) $\mathrm{HSC}$

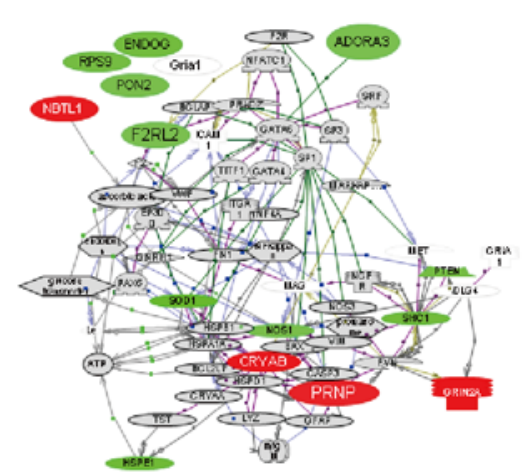

(D) $\mathrm{BEC}$

图 55 种细胞中的缺血反应特殊基因在大鼠肝再生中的表达变化和网络联系

红色示肝再生中表达上调基因; 绿色示下调基因; 白色示上/下调基因; 灰色示未发生有意表达变化基因. (A) DC 特殊基因互作图;

(B) HSC 特殊基因互作图; (C) KC 特殊基因互作图; (D) BEC 特殊基因互作图; (E) HC 特殊基因互作图

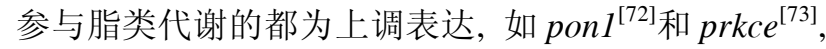
且在 $2 \mathrm{~h}$ 就起始表达, 说明缺血反应能激发肝再生启 动阶段的能量释放.

综上, 部分肝切除后的局部缺血, 能因为引发 $i l 6, \operatorname{tnf}$ 等基因表达来促进肝再生的进行 ${ }^{[74,75]}$, 且 $i l 6$ 由 BEC, DC, KC, HSC, OC 表达产生, $t n f$ 由 $\mathrm{KC}, \mathrm{LC}$, $\mathrm{OC}$ 表达产生. 除了稳定血压、血管再生、细胞增殖、 细胞调亡、炎症反应、激活信号通路这些共同功能外, 由于每种细胞存在只在自身表达的基因, 使一些细 胞发挥了独特的功能. DC 中表达的基因与抑制免疫
应答有关，避免局部缺血后血流走向改变、血管再生 引发过激免疫反应; $\mathrm{KC}$ 中表达与 DNA 修复、阻滞细 胞周期、参与神经递质传导的基因; HSC 的基因能进 行脂类代谢, 可以为缺血后肝再生进行提供能量支 持; $\mathrm{HC}$ 能解决缺血后的局部水肿. 上述结果为将来 解决肝脏移植过程出现的缺血再灌注损伤, 提供了 一定的理论依据. 但是, 这 8 种肝脏细胞中 BEC 情况 特殊, 有很多以前研究的与神经缺血反应相关的基因 发生了变化, 且 BEC 中有些下调表达变化的基因, 还 有很多上下调变化的基因, 情况复杂, 需进一步研究.

\section{参考文献}

1 Kirimlioglu V, Kirimlioglu H, Yilmaz S, et al. Effect of fish oil, olive oil, and vitamin E on liver pathology, cell proliferation, and antioxidant defense system in rats subjected to partial hepatectomy. Transplant Proc, 2006, 38: 564-567

2 Xu C S, Chang C F, Yuan J Y, et al. Expressed genes in regenerating rat liver after partial hepatectomy. World J Gastroenterol, 2005, 11: 
$2932-2940$

3 Fausto N. Liver regeneration. J Hepatol, 2000, 32: S19-S231

4 Gregory R. The blind leading the sighted. Nature, 2004, 430: 836

5 Drixler T A, Vogten M J, Ritchie E D, et al. Liver regeneration is an angiogenesis- associated phenomenon. Ann Surg, 2002, 236: 703-711

6 Kitamura Y, Usami M, Kotani G, et al. Endothelin in liver cell injury and regeneration after $70 \%$ hepatectomy with portal ischemia. J Cardiovasc Pharmacol, 1998, 31: S480-481

7 Cimica V, Batusic D, Haralanova-Ilieva B, et al. Serial analysis of gene expression (SAGE) in rat liver regeneration. Biochem Biophys Res Commun, 2007, 360: 545-552

8 Higgins G M, Anderson R M. Experimental pathology of the liver: restoration of the liver of the white rat following partial surgical removal. Arch Patho, 1931, 12: 186-202

9 De Smet K, Beken S, Vanhaecke T, et al. Isolation of rat hepatocytes. Methods Mol Biol, 1998, 107: 295-301

10 Sells M A, Katyal S L, Shinozuka H, et al. Isolation of oval cells and transitional cells from the livers of rats fed the carcinogen DL-ethionine. J Natl Cancer Inst, 1981, 66: 355-362

11 Ramm G A. Isolation and culture of rat hepatic stellate cells. J Gastroenterol Hepatol, 1998, 13: 846-851

12 Tsutsumi M, Takada A, Takase S. Characterization of desmin-positive rat liver sinusoidal cells. Hepatology, 1987, 7: 277-284

13 Munthe-Kaas A C, Berg T, Seglen P O, et al. Mass isolation and culture of rat kupffer cells. J Exp Med, 1975, 141: 1-10

14 Starkey P M, Sargent I L, Redman C W. Cell populations in human early pregnancy decidua: characterization and isolation of large granular lymphocytes by flow cytometry. Immunology, 1988, 65: 129-134

15 Klinkert W E F, Labadie J H, We B. Accessory and stimulating properties of dendritic cells and macrophages isolated from various rat tissues. J Exp Med, 1982, 156: 1

16 Lü M D, Miyazaki K S Y. Isolation and culture of bile duct epithelial cells as an useful tool for screening of biliary tract carcinogens.. Nippon Geka Gakkai Zasshi, 1989, 90: 404-408

17 Adams J C. Biotin amplification of biotin and horseradish peroxidase signals in histochemical stains. J Histochem Cytochem, 1992, 40: $1457-1463$

18 Longnecker D S. A program for automated hematoxylin and eosin staining. Am J Clin Pathol, 1966, 45: 229

19 Knepp J H, Geahr M A, Forman M S, et al. Comparison of automated and manual nucleic acid extraction methods for detection of enterovirus RNA. J Clin Microbiol, 2003, 41: 3532-3536

20 Nuyts S, Van Mellaert L, Lambin P, et al. Efficient isolation of total RNA from Clostridium without DNA contamination. J Microbiol Methods, 2001, 44: 235-238

21 Arkin A, Ross J, McAdams H H. Stochastic kinetic analysis of developmental pathway bifurcation in phage lambda-infected Escherichia coli cells. Genetics, 1998, 149: 1633-1648

22 Li L, Roden J, Shapiro B E, et al. Reproducibility, fidelity, and discriminant validity of mRNA amplification for microarray analysis from primary hematopoietic cells. J Mol Diagn, 2005, 7: 48-56

23 Collins J F. Gene chip analyses reveal differential genetic responses to iron deficiency in rat duodenum and jejunum. Biol Res, 2006, 39 : $25-37$

24 Twigger S N, Smith S J, Zuniga-Meyer A, et al. Exploring phenotypic data at the rat genome database. Curr Protoc Bioinformatics, 2006, Chapter 1: Unit 1.14

25 Wang J Z, Du Z, Payattakool R, et al. A new method to measure the semantic similarity of GO terms. Bioinformatics, 2007, 23: 12741281

26 Guo W, Cai C, Wang C, et al. A preliminary analysis of genome structure and composition in Gossypium hirsutum. BMC Genomics, 2008, 9: 314

27 Bult C J, Eppig J T, Kadin J A, et al. The Mouse Genome Database (MGD): mouse biology and model systems. Nucleic Acids Res, 2008, 36: D724-D728

28 Doniger S W, Salomonis N, Dahlquist K D, et al. MAPPFinder: using Gene Ontology and GenMAPP to create a global gene-expression profile from microarray data. Genome Biol, 2003, 4: R7

29 Fleige S, Walf V, Huch S, et al. Comparison of relative mRNA quantification models and the impact of RNA integrity in quantitative real-time RT-PCR. Biotechnol Lett, 2006, 28: 1601-1613

30 Guo W, Cai C, Wang C, et al. A preliminary analysis of genome structure and composition in Gossypium hirsutum.. BMC Genomics, 2008, 9: 314 
31 Strausberg R L, Camargo A A, Riggins G J, et al. An international database and integrated analysis tools for the study of cancer gene expression. Pharmacogenomics J, 2002, 2: 156-164

32 Michalopoulos G K. Liver regeneration after partial hepatectomy: critical analysis of mechanistic dilemmas. Am J Pathol, 2010, 176: 2-13

33 Baier P, Wolf-Vorbeck G, Hempel S, et al. Effect of liver regeneration after partial hepatectomy and ischemia-reperfusion on expression of growth factor receptors. World J Gastroenterol, 2006, 12: 3835-3840

34 Stolz D B, Ross M A, Ikeda A, et al. Sinusoidal endothelial cell repopulation following ischemia/reperfusion injury in rat liver transplantation. Hepatology, 2007, 46: 1464-1475

35 Kuboki S, Shin T, Huber N, et al. Hepatocyte signaling through CXC chemokine receptor-2 is detrimental to liver recovery after ischemia/ reperfusion in mice. Hepatology, 2008, 48: 1213-1223

36 Boros P, Bromberg J S. New cellular and molecular immune pathways in ischemia/reperfusion injury. Am J Transplant, 2006, 6: 652—658

37 He S, Atkinson C, Qiao F, et al. A complement-dependent balance between hepatic ischemia/reperfusion injury and liver regeneration in mice. J Clin Invest, 2009, 119: 2304-2316

38 Norat T, Bowman R, Luben R, et al. Blood pressure and interactions between the angiotensin polymorphism AGT M235T and sodium intake: a cross-sectional population study. Am J Clin Nutr, 2008, 88: 392-397

39 Le T H, Kim H S, Allen A M, et al. Physiological impact of increased expression of the AT1 angiotensin receptor. Hypertension, 2003, 42: $507-514$

40 Wolfe F, Zhao S, Pettitt D. Blood pressure destabilization and edema among 8538 users of celecoxib, rofecoxib, and nonselective nonsteroidal antiinflammatory drugs (NSAID) and nonusers of NSAID receiving ordinary clinical care. J Rheumatol, 2004, 31: 1143-1151

41 Pan L H, Beppu T, Kurose A, et al. Neoplastic cells and proliferating endothelial cells express connective tissue growth factor (CTGF) in glioblastoma. Neurol Res, 2002, 24: 677-683

42 Liu L, Zhu D, Gao R, et al. Expression of vascular endothelial growth factor, receptor KDR and p53 protein in transitional cell carcinoma of the bladder. Urol Int, 2008, 81: 72-76

43 Haddad R, Romero R, Gould B R, et al. Angiogenesis gene expression in mouse uterus during the common pathway of parturition. Am J Obstet Gynecol, 2008, 198: 539

44 Renner W, Koppel H, Hoffmann C, et al. Prothrombin G20210A, factor V Leiden, and factor XIII Val34Leu: common mutations of blood coagulation factors and deep vein thrombosis in Austria. Thromb Res, 2000, 99: 35-39

45 Park Y M, Park M Y, Suh Y L, et al. NAD(P)H oxidase inhibitor prevents blood pressure elevation and cardiovascular hypertrophy in aldosterone-infused rats. Biochem Biophys Res Commun, 2004, 313: 812-817

46 Muraoka O, Xu B, Tsurumaki T, et al. Leptin-induced transactivation of NPY gene promoter mediated by JAK1, JAK2 and STAT3 in the neural cell lines. Neurochem Int, 2003, 42: 591-601

47 Takami T, Kaposi-Novak P, Uchida K, et al. Loss of hepatocyte growth factor/c-Met signaling pathway accelerates early stages of N-nitrosodiethylamine induced hepatocarcinogenesis. Cancer Res, 2007, 67: 9844-9851

48 Scheving L A, Stevenson M C, Taylormoore J M, et al. Integral role of the EGF receptor in HGF-mediated hepatocyte proliferation. Biochem Biophys Res Commun, 2002, 290: 197-203

49 Fasen K, Cerretti D P, Huynh-Do U. Ligand binding induces Cbl-dependent EphB1 receptor degradation through the lysosomal pathway. Traffic, 2008, 9: 251-266

50 Meng S, Qiao M, Lin L, et al. Correspondence of AQP4 expression and hypoxic-ischaemic brain oedema monitored by magnetic resonance imaging in the immature and juvenile rat. Eur J Neurosci, 2004, 19: 2261-2269

51 Schmeer C, Gamez A, Tausch S, et al. Statins modulate heat shock protein expression and enhance retinal ganglion cell survival after transient retinal ischemia/reperfusion in vivo. Invest Ophthalmol Vis Sci, 2008, 49: 4971-4981

52 Kaeser P S, Klein M A, Schwarz P, et al. Efficient lymphoreticular prion propagation requires $\operatorname{PrP}(\mathrm{c})$ in stromal and hematopoietic cells. J Virol, 2001, 75: 7097-7106

53 Kuo S M, Tan C H, Dragan M, et al. Endotoxin increases ascorbate recycling and concentration in mouse liver. J Nutr, 2005, 135: 24112416

54 Dhar S S, Wong-Riley M T. Coupling of energy metabolism and synaptic transmission at the transcriptional level: role of nuclear respiratory factor 1 in regulating both cytochrome c oxidase and NMDA glutamate receptor subunit genes. J Neurosci, 2009, 29: 483—492

55 Pugliese A M, Coppi E, Volpini R, et al. Role of adenosine A3 receptors on CA1 hippocampal neurotransmission during oxygen-glucose deprivation episodes of different duration. Biochem Pharmacol, 2007, 74: 768-779

56 Zhang L, Schessl J, Werner M, et al. Role of GluR1 in activity-dependent motor system development. J Neurosci, 2008, 28: 9953-9968 
57 Domeniconi M, Zampieri N, Spencer T, et al. MAG induces regulated intramembrane proteolysis of the p75 neurotrophin receptor to inhibit neurite outgrowth. Neuron, 2005, 46: 849-855

58 Song B, Yan X B, Zhang G Y. PSD-95 promotes CaMKII-catalyzed serine phosphorylation of the synaptic RAS-GTPase activating protein SynGAP after transient brain ischemia in rat hippocampus. Brain Res, 2004, 1005: 44-50

59 Nadaud S, Mao C, Luvara G, et al. Isoform-specific regulation of nitric oxide synthase mRNA in the kidney by sodium and blood pressure. J Hypertens, 1998, 16: 1315-1323

60 Pei L, Castrillo A, Chen M, et al. Induction of NR4A orphan nuclear receptor expression in macrophages in response to inflammatory stimuli. J Biol Chem, 2005, 280: 29256-29262

61 Liu J, Miwa T, Hilliard B, et al. The complement inhibitory protein DAF (CD55) suppresses T cell immunity in vivo. J Exp Med, 2005, 201: $567-577$

62 Lin W H, Wu C H, Chen Y C, et al. Embryonic expression of zebrafish AMPA receptor genes: zygotic gria2alpha expression initiates at the midblastula transition. Brain Res, 2006, 1110: 46-54

63 Amano K, Matsubara H, Iba O, et al. Enhancement of ischemia-induced angiogenesis by eNOS overexpression. Hypertension, 2003, 41: $156-162$

64 Chen D, Minami M, Henshall D C, et al. Upregulation of mitochondrial base-excision repair capability within rat brain after brief ischemia. J Cereb Blood Flow Metab, 2003, 23: 88-98

65 Vleugel M M, Greijer A E, Bos R, et al. c-Jun activation is associated with proliferation and angiogenesis in invasive breast cancer. Hum Pathol, 2006, 37: 668-674

66 Duka A, Duka I, Gao G, et al. Role of bradykinin B1 and B2 receptors in normal blood pressure regulation. Am J Physiol Endocrinol Metab, 2006, 291: E268-E274

67 Kubli D A, Quinsay M N, Huang C, et al. Bnip3 functions as a mitochondrial sensor of oxidative stress during myocardial ischemia and reperfusion. Am J Physiol Heart Circ Physiol, 2008, 295: H2025-2031

68 Tirosh O, Pardo M, Schwartz B, et al. Long-lived alphaMUPA transgenic mice show reduced SOD2 expression, enhanced apoptosis and reduced susceptibility to the carcinogen dimethylhydrazine. Mech Ageing Dev, 2005, 126: 1262-1273

69 Scoazec J Y, Borghi-Scoazec G, Durand F, et al. Complement activation after ischemia-reperfusion in human liver allografts: incidence and pathophysiological relevance. Gastroenterology, 1997, 112: 908-918

70 Rohatgi T, Henrich-Noack P, Sedehizade F, et al. Transient focal ischemia in rat brain differentially regulates mRNA expression of protease-activated receptors 1 to 4. J Neurosci Res, 2004, 75: 273-279

71 Nakken K E, Nygard S, Haaland T, et al. Multiple inflammatory-, tissue remodelling- and fibrosis genes are differentially transcribed in the livers of Abcb4 (-I-) mice harbouring chronic cholangitis. Scand J Gastroenterol, 2007, 42: 1245-1255

72 Beltowski J, Wojcicka G, Jamroz A. Leptin decreases plasma paraoxonase 1 (PON1) activity and induces oxidative stress: the possible novel mechanism for proatherogenic effect of chronic hyperleptinemia. Atherosclerosis, 2003, 170: 21-29

73 Samuel V T, Liu Z X, Qu X, et al. Mechanism of hepatic insulin resistance in non-alcoholic fatty liver disease. J Biol Chem, 2004, 279: 32345-32353

74 Sudo K, Yamada Y, Saito K, et al. TNF-alpha and IL-6 signals from the bone marrow derived cells are necessary for normal murine liver regeneration. Biochim Biophys Acta, 2008, 1782: 671—679

75 Tiberio G A, Tiberio L, Benetti A, et al. IL-6 Promotes compensatory liver regeneration in cirrhotic rat after partial hepatectomy. Cytokine, 2008, 42: $372-378$ 


\title{
The Function Analysis Between Ischemia Response-Related Genes In Eight Liver Cell Types And Rat Liver Regeneration
}

\author{
FANG Fang $^{1,2} \&$ XU CunShuan ${ }^{2}$ \\ 1 Department of Human Anatomy, Xinxiang Medical University, Xinxiang 453003, China; \\ 2 Key Laboratory for Cell Differentiation Regulation, Henan Normal University, Xinxiang 453007, China
}

\begin{abstract}
For understanding the relationship between eight hepatic cells and rat liver regeneration, we separate the regenerating livers' cells after partial hepatectomy $(0,2,6,12,24,30,36,72,120$ and 168 h) by percoll density gradient centrifugation and immunomagnetic selection, detect the ischemia reaction associated genes' expression changes in the cells above by Rat Genome 2302.0 chips, and analyze the relativity between these genes and rat liver regeneration by using biology and system biology. The results display that ischemia responses mainly play role at liver regeneration initial and progression phases, can stimulate the expression of liver regeneration key genes such as IL6 and TNF. The expression genes in BECs, HSCs and DCs have similarities. Ischemia response can push the liver regeneration smoothly, but BECs' gene expression is different to other cells which need to research further.
\end{abstract}

liver regeneration, partial Hepatectomy, rat Genome 2302.0 chip, ischemia response

doi: $10.1360 / 052010-252$ 